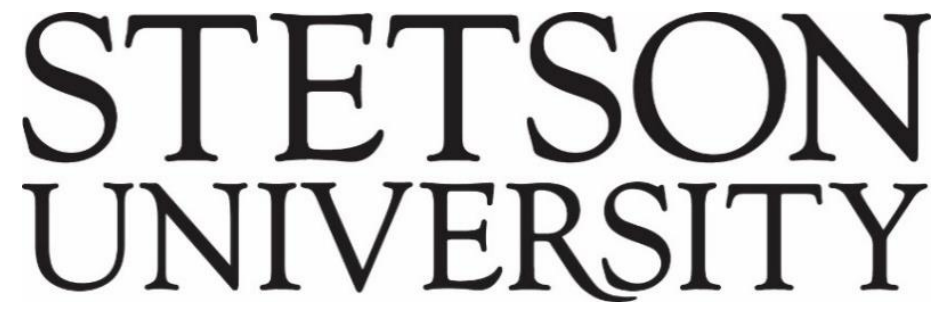

Voices of Reform: Educational Research to Inform and Reform

Volume $1 \bullet$ Issue $1 \bullet$ Article 2

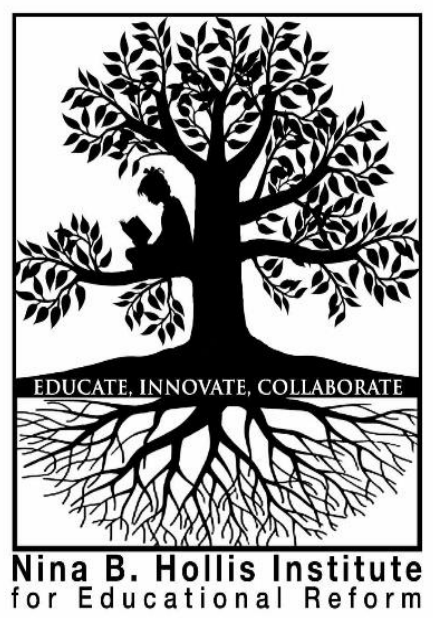

September 2018

\title{
Districts of Innovation: Combating a Wicked Problem in Education
}

Joshua Childs

University of Texas at Austin

Follow this and additional works at: http://www.voicesofreform.com

Recommended Citation

Childs, J. (2018). Districts of innovation: Combating a wicked problem in education. Voices of Reform, 1(1), 23-

40. Retrieved from https://www.voicesofreform.com/article/4485-districts-of-innovation-combating-a-wickedproblem-in-education. doi: 10.32623/1.00004

http://dx.doi.org/10.32623/1.00004

Revisions

Submission date: June $11^{\text {th }}, 2018$

$1^{\text {st }}$ Revision: August $30^{\text {th }}, 2018$

Acceptance: August $31^{\text {st }}, 2018$

Publication date: September $15^{\text {th }}, 2018$ 


\title{
Districts of Innovation: Combating a Wicked Problem in Education
}

\author{
Joshua Childs ${ }^{1}$ \\ ${ }^{1}$ Department of Educational Administration \\ University of Texas at Austin, United States \\ joshuachilds@austin.utexas.edu
}

\begin{abstract}
The word innovation can mean a number of things to different stakeholders and policymakers. This discourse analysis examines how the Texas Education Agency (TEA) has used an initiative called Districts of Innovation to attempt to support and empower districts throughout the state of Texas. The question becomes whether those attempts are symbolic or actually do innovate school districts to appropriately improve and reform their schools. A critical case study of three Independent School Districts in Texas provides a policy framework to examine the intersection between autonomy and innovation and how this inevitably impacts school improvement. Findings indicate absences of realistic assessment, the desire to do "too much too soon," and the absence of meaningful oversight.
\end{abstract}

\section{Keywords}

charter schools, innovation, discourse analysis, policy framing, Independent School Districts

\section{Introduction}

In recent years, policymakers have instituted various autonomy initiatives as a school improvement strategy, all of which underscore innovation as a critical ingredient for change. In some understandings, autonomy is the innovation in and of itself. Other initiatives, however, assume that schools operating with increased agency will have a new capacity for innovation, and it is assumed that innovative practices will be the direct result of autonomy (e.g. Honig \& Rainey, 2012). Charter schools, for instance, are presented by some as an institutional innovation in which law allows schools to operate under an autonomous structure of governance (Bulkley \& Fisler, 2003). Lubienski (2003) suggests charter schools are intended to be organizationally innovative, freed by measures of autonomy to innovate in areas such as teacher merit pay and parent contracts. Still others contend that the intended innovation permitted by charter school policy should be implemented within the classroom. In a review of charter laws, Wohlstetter et al. (2013) found that "more than ninety percent of the state charter laws included as one of the purposes behind the law 
to encourage school communities to use their autonomy in the classroom to experiment, innovate, and create new educational options for students" (p. 38). In the 2000s, "contemporary autonomy initiatives" (p. 466) emerged with a focus on how school freedoms would lead to better teaching and learning.

One such autonomy initiative in Texas, Districts of Innovation (DOI), is written such that traditional independent school districts have "most of the flexibilities available to Texas' openenrollment charter schools" (TASB, 2018). The focus of DOI policy is local control enabling customized plans - including the option to exempt from state mandates - for individual schools or groups of schools within the district. The new freedoms should, per policy design, contribute both directly and indirectly to improvements in teaching and learning.

\section{Policy Instruments}

As part of its strategic planning process, the Texas Education Agency (TEA) has identified ways to support and empower districts in efforts to improve low-performing campuses and unburden higher performing ones. This has been done through the adoption of four new initiatives: School Redesign Fund; System of Great Schools; Transformation Zone Grant; and Districts of Innovation (TEA, 2018). All employ political heuristics in the promise for "empowerment in autonomy" and incentivize either operation with, or in the vein of, charter schools by removing local barriers.. Each of these agency initiatives is based on the ideological assumption that increased autonomy will enable schools to develop and implement novel approaches to teaching and learning, and incentivize achievement through access to exemptions.

In addition to the underlying ideological framework, DOI strategically employs language to frame policy symbolically and associate it positively in the minds of the taxpaying public and implementers on the ground. The term "innovation" alludes to new and improved methods, ideas, or practices, sometimes groundbreaking or paradigm shifting. It is frequently associated with technological advancement and the disruption of older, less effective systems. "Educational innovation" is also a term employed for decades by proponents of charter schools who have used it as a discursive tool invoking scientific and technological approaches to teaching and learning, going so far as to call their schools "educational laboratories." By labeling exemptions as "innovations," policy makers have been able to make positive associations to other, more respected industries (business, science) and also muddy the waters around concerns with deregulation that can remove hard-won protections for vulnerable stakeholders in public education.

DOI policy also employs incentive tools. In an analysis of the behavioral assumptions of policy tools, Schneider and Ingram (1990) advance that "public policy almost always attempts to get people to do things that they might otherwise not do; or it enables people to do things that they might not have done otherwise" (p. 513). Incentive policy tools manipulate the tangible benefits, costs, and probabilities that policymakers assume are relevant to the situation, although target populations may perceive many other values, both tangible and intangible. Incentives also assume that individuals have the opportunity to make choices, recognize that opportunity, and have adequate information to select alternatives that are in their own best interests (Schneider \& Ingram, 1990). Of performance, education economist Eric Hanushek suggests, "it is really hard to regulate 
higher achievement, [it is] really hard to set up a regulatory structure that leads to better performance. For an economist, the alternative is to set up an incentive structure to get the actors in the system working to get the outcomes that you want, and that in general tries to be more effective than regulations" (Hanushek, 2018). DOI policy incentivizes improved or sustained academic performance by providing districts increased freedom from regulation after they have met a minimum standard of achievement. In order to become a DOI, a school district's most recent academic performance rating must be acceptable or better. In this way, TEA gatekeeping to participation manipulates costs and benefits for districts seeking greater flexibility and local control.

\section{Policy Context}

\section{National Background}

Since de jure segregation in the middle of the 20th century, the federal and state governments have taken on increasingly large roles in the improvement of schools. Following de facto segregation and the school finance reform movement of the 1960s and 70s, A Nation at Risk (1983) and anxiety about global competitiveness during the Cold War compelled states to expand the scope of regulation to include core issues of classroom practice in the 1980s. While overall achievement lagged and class- and race-based gaps persisted, the federal government passed the 2002 No Child Left Behind (NCLB) requiring states to assess whether schools were making Adequate Yearly Progress (AYP), and schools that failed repeatedly to make AYP suffered penalties and sanctions intended to spur improvement (Leithwood, Harris, \& Strauss, 2010). NCLB increased attention and resources on low-income students and used disaggregated data to identify achievement gaps (Fusarelli, 2004). It also established the School Improvement Grants (SIGs) program. Between 2007 and 2015, the U.S. Department of Education (USDOE) spent nearly \$8 billion on the program with the goal of increased student achievement for these "failing" schools (Emma, 2015). However, a 2012 government survey found that most SIG-funded schools failed to meet their annual objectives (Van Gronigen \& Meyers, 2017). Following NCLB, in 2009 the USDOE launched the Race to the Top (RttT) federal grant competition program that allocated funds to ambitious state-led education reform agendas, including those that promoted educational innovation and the expansion of charter schools (Childs \& Russell, 2016). Today, the movement pairing school accountability for student achievement with the devolution of decision-making authority to the school site in areas that affect student achievement, such as curriculum, staffing, and the use of resources continues to be a popular educational reform across the country.

\section{Charter Theory and Efforts to Deregulate Schooling}

Since the late 1980's, states have been under pressure to deregulate schooling and devolve additional authority to districts and schools. During this "second wave" of reform, waivers and pilot deregulatory efforts were generally limited to just a few "low-risk" schools/districts that implemented relatively modest changes few could call innovative (Elmore \& Fuhrman, 1995). While the stated goal of this differential treatment from states has been to increase local autonomy, education policy implementation scholars have argued that these early iterations of local empowerment were nothing more than an illusion (Malen, 2003). As the charter movement in the 
1990's and other more contemporary autonomy initiatives have emerged, incentivizing and empowering schools to innovate through increased autonomy has continued to have a decidedly mixed track record.

In recent decades, policymakers in a number of countries have been embracing market mechanisms such as choice and competition to reform education. School choice policy aims to improve educational quality through the workings of competition whereby, in theory, school choosers will have access to perfect information and will employ rational choice in selecting schools that offer the best product. Schools will then respond competitively by making substantive changes such as improving educational services and enhancing efficiency (Chubb \& Moe, 1988; Friedman, 2009). The theoretical aim of granting greater autonomy to charter schools is that it will encourage innovative educational models that will spill over into underperforming schools, resulting in better outcomes for all students (Berends, 2015). Though the charter sector in Texas is not yet as large as that of many other states, this is changing quickly due in large part to legislation and TEA grants incentivizing both autonomy and charter expansion - almost as synonymous initiatives - both within and beyond traditional school districts (TEA, 2018).

Some studies have shown that charter schools' autonomy can, in certain contexts, facilitate the implementation of effective structures and processes (Bryk et al. 2010, Gleason 2014, Goldring \& Berends, 2009), but Preston et al.'s (2012) study analyzing over 200 charter schools and over 700 traditional public schools in 36 states found that charter schools did not fulfill the expectations for innovation when compared with traditional public schools.

\section{Colorado Innovation Schools and Zones}

Colorado is a state with a long history of encouraging educational reform through autonomy and innovation in public and charter schools. Their Innovations Schools Act in 2008 presaged what would become Texas' DOI policy several years later. The Innovation Schools Act of 2008 was designed to create a pathway for schools and districts to develop and implement innovative school practices in a variety of areas. It provided a formal process that allowed individual schools or groups of schools to petition their local school boards for waivers from district-level policies and for school boards to petition to the Colorado State Board of Education for waivers from certain state-level laws and regulations. According to the Colorado Department of Education (CDE), the Colorado general assembly sought a variety of outcomes including: to grant school districts and public schools greater ability to meet the educational needs of a diverse and constantly changing student population; to encourage intentionally diverse approaches to learning and education within individual school districts; to improve educational performance through greater individual autonomy and managerial flexibility; to encourage school districts to create and manage a portfolio of schools that meet a variety of education needs; and to encourage school districts and public schools to find new ways to allocate resources for the benefit of the students they serve (Colorado Department of Education, 2018). Under the legislation, the State Board of Education designates a school district as a "district of innovation," and then this designation permits a district of innovation to approve or collaboratively create an innovation school or an innovation school zone, comprised of a group schools that share common interests, like geographical location or educational focus. 
The process and guidelines for seeking innovation school or zone status include multiple steps. First is to develop an innovation plan by collaborating with school administrators, staff, the school Accountability Committee, and the broader school community. Innovation school and school zone applications must include evidence that a majority of administrators employed at the school, majority of teachers employed at the school, and majority of the School Accountability Committee members consent to the plan. The next step is to seek waivers and approval of the plan. A school or group of schools submit their innovation plan to the local school board which approves or rejects the plan. If the local school board approves a plan that includes requests for waivers from state statutes or regulations, not just district policy, they must then submit the plan to the commissioner for approval. From this point, the commissioner and state board of education have 60 days to suggest changes to the plan that would result in greater academic achievement. Districts also have an opportunity to take the feedback and resubmit. Once the plan is complete, the state board has 60 days to determine whether to approve or deny the plan. If the state board denies the plan, it must submit a written explanation of the basis for its decision. Waiver of collective bargaining rights in an approved plan requires a $60 \%$ approval from teachers in the school(s) affected. Finally, once a plan is approved, waivers are put in effect immediately and every three years the school board must review the performance of the school(s) and determine whether the school or zone is achieving or making adequate progress toward achieving the performance results pursued in the plan.

\section{Birth of Texas' Districts of Innovation Legislation}

The section of House Bill 1842 regarding districts of innovation was originally filed as standalone legislation by then-Senate Education Committee Chairman Larry Taylor ( $\mathrm{R}$ - Friendswood). Senate Bill 1241, "relating to authority of school districts, home-rule school districts, and openenrollment charter schools to establish innovation zones and the authority of school districts to obtain designation as districts of innovation," was comprised of two subchapters: subchapter A outlines the rules governing the provision of a multiple-campus innovation zone, while subchapter $\mathrm{B}$ outlines the rules governing the provision of a district's designation as a district of innovation. Innovation zones were intended to "encourage local community-based initiatives to improve educational outcomes with minimum state and local requirements; to enable collaboration by multiple campuses, programs, and institutions of higher education; and to encourage innovation through shared resources and facilities (Texas Legislature Online, 2018). DOI, on the other hand, simply requires that a locally-developed plan provide for a comprehensive educational program for the district at-large and identify requirements imposed by state code that inhibit the goals of the plan.

On May 26, 2015, Taylor amended subchapter B of Senate Bill 1241 onto House Bill 1842 in its original text. The bill rode favorably as amended through the Senate vote and on to the governor, who on June 19, 2015 signed into law either the potential for districts to innovate beyond the confines of the state's regulatory framework, or the potential to relinquish the statutory safety net of public schools altogether (2018). According to the Texas Education Agency (TEA) there are currently 753 districts in the state of Texas that have notified TEA that they have adopted a local innovation and are designated as an Innovation District. Senator Larry Taylor, is a well-known 
advocate of so-called "school choice" and other market-based educational reforms such as education savings accounts (ESAs), tax credit scholarships, and school vouchers.

In the first public hearing for Senate Bill 1241, Senator Taylor explained that the bill "seeks to build on the success of high-performing traditional and charter schools, and provide school districts with increased autonomy and flexibility to meet the unique needs of their students." (SB1241, Senate Committee on Education Hearing, April 2015).

\section{Policy Context}

The $84^{\text {th }}$ Legislative Session enacted into law House Bill 1842 (2015), "relating to public school accountability, including...the designation of a school as a district of innovation" (Texas Legislature Online, 2018). The statute, found in Chapter 12A of the Texas Education Code (TEC), provides that a traditional independent school district (ISD) rated acceptable or better can create a district-level Local Innovation Plan (LIP) and may choose in the plan to claim exemption from sections of the Texas Education Code (TEC) from which Texas public charter schools are exempt. While there is no comprehensive list of exemptions available to DOI, legal requirements of which districts commonly opt out include statutes regarding: class size and student/teacher ratio; teacher certification; teacher contracts and benefits; student discipline provisions; teacher and principal appraisal systems; uniform school calendars; and minimum minutes of instruction. An LIP cannot seek exemption from state or federal requirements applicable to open enrollment charter schools including, but not limited to: bilingual education, special education, and district governance regulations including the powers and duties of school boards, superintendents, and principals (TASB, 2018). Per TEA representative Lisa Hughes, "the agency posts individual plans on the TEA website, but [does] not track districts' specific exemptions" (Hughes, 2018).

TEA has rulemaking authority regarding the implementation of DOI, though LIPs are not subject to approval by the agency (TEA, 2018). In other words, while there is a specific process that districts are required to follow in designating themselves as a DOI, the Commissioner of Education ultimately has no jurisdiction over the LIP unless the district receives an unacceptable academic and/or financial performance rating for three consecutive years, in which case the district must return to compliance with all specified areas of the TEC by a date to be determined by the commissioner (TASB, 2018).

The process of becoming a designated DOI begins either with a resolution by a district board of trustees or by way of a signed petition from a majority of the district-level advisory committee. The board is required to hold a public hearing regarding its consideration to develop a LIP, and within 30 days of the hearing must formally decide to pursue (or decline) designation as an innovative district. The board then appoints an Innovation Plan Committee to write a plan that "provides for a comprehensive educational program for the district" (TEA, 2018). Once the LIP has been drafted and posted on the district website for at least 30 days, the board must notify the commissioner of the intent to adopt it. The advisory committee must then approve the plan with a majority vote, and finally, with a two-thirds majority vote by the board of trustees and a submission of the LIP to the commissioner, an ISD becomes a designated district of innovation. 
Three DOI cases from Central Texas- Austin Independent School District (AISD), Eanes Independent School District (EISD), and Manor Independent School District (MISD) have been selected for this discourse analysis.

\section{Methodology}

\section{Discourse Analysis}

To investigate the manner in which Austin, Eanes, and Manor ISDs implement the DOI policy and engage policy tools, I employed document analysis of the LIPs. Document analysis is a research method that involves the systematic reading of text as a means of gaining insight into meaningful elements of content (Bowen, 2009). Because the documents were short and easily analyzed "by hand," the methods - though grounded in the theories of discourse analysis - were not formally analyzed using qualitative analysis software or research-based coding techniques.

\section{Case Selection}

I focused on three neighboring Central Texas school districts for three primary reasons. First, at the outset of the project design, I intended to collect interview data to supplement the discourse analysis, and I only had contacts in each of these three districts and assumed face-to-face interviews would be relatively easy to manage. Second, all three districts filed their innovation plans with TEA in the same year. Finally, I felt that because the three districts were located in the same urban metropolis and yet comprised significantly different contexts (in terms of size, demographic, history, and tax base), it would provide an interesting data set.

\section{Data Analysis}

I conducted an initial reading of each of the documents for a general sense of the tone of the plans. It was evident that each document was crafted from a different perspective and for a different audience. I conducted a word count of some of the variations of the terms that had been found in our earlier research to be meaningful in the policy and have symbolic value: innovation, innovative, innovate, autonomy, local control, local, flexibility, and flexible. Each of these three categories of words reflect language in the bill itself as well as in the archived testimony, news, and policy briefs both for and against the policy. Second, I analyzed the overall structure of the document, including its length and the way in which it was organized and formatted. Finally, I examined what could be understood to be the core of the innovation plans, the exemptions. I analyzed the way in which the exemptions were introduced in the document, and I counted the number of codes each district required exemption from. Finally, after multiple readings of each of the three innovation plans, I selected quotes that I felt best reflected the goals and tone of the document. After the individual document analysis data was fully collected, I compared and contrasted each of the data sets. In this way, I was able to identify which elements of the documents were shared by any or all of the districts and what elements stood out as unique. 


\section{Findings}

\section{Austin Independent School District}

In early fall 2016, the AISD Board of Trustees unanimously approved a resolution to begin the process of becoming a designated DOI. Large by comparison to the other districts in this study, the innovation plan committee consisted of a 36-member team representing students, teachers, administrators, parents, and community members from each of the eleven AISD vertical teams, along with all nine trustees. "In an effort to reinvent the urban school experience" (Austin Independent School District Local Innovation Plan, 2016, p. 2) and in affirmation of the district's "commitment to high quality teaching and instruction" (AISD Plan, 2016, p. 2), the LIP elucidated how the AISD innovation committee focused primarily and specifically on exploring innovations that would give additional time to teachers for professional development, lesson planning, and preparation. Throughout the document there was significant mention of the need for teachers to have more student-free planning and training time to not only increase preparedness and professional collaboration, but also decrease teacher burnout.

Austin ISD's LIP had the most comprehensive overall district vision in its macro-level connections to state code and internal alignment between innovations and the overall strategic plan. The document was organized around the "Strategic Plan Framework" (AISD Plan, 2016, p. 5), and in the first several pages, it introduced the district vision, mission, core beliefs, values, and innovations. It then outlined the district's three core beliefs centered on generating effective students, building and maintaining an effective organization, and developing effective relationships. It also promised to value community-centric virtues such as health, diversity, and of course, innovation. This framing represented a clear articulation of a shared mission and vision, a policy goal of DOI legislation. The LIP exempted the district from a total of eight state codes that were organized into four categories of need: educator certification; minutes of instruction; first and last day of instruction; and minimum attendance required. In each of the categories of need, the plan listed an average of twelve current challenges, the exemptions by code, and an explanation of the challenge and rationales related to the code exemptions. Some variant of the word "innovation" was used nearly sixty times, the notion of local control was invoked twenty times, and "flexibility" was mentioned thirteen times.

The Educator Certification innovation section that sought to create more CTE and field-based learning opportunities for students cited a lack of highly qualified staff for innovative and specialized courses along with competition from charter schools as challenges that necessitated certain exemptions. Flexibility to hire "industry professionals" was the guiding principle, but the exemptions also revealed a strategic response to the gap in qualified teachers for certain specialized CTE positions. With an influx of new-to-the-industry educators unfamiliar with the norms and practices of the profession, challenges to implementation could arise.

Both the Minutes of Instruction and the Minimum Attendance sections identified insufficient planning and preparation time along with insufficient time for teacher collaboration as key challenges that demanded a more innovative approach. Additional flexibility in the daily and yearly schedule could provide opportunities to develop social capital through increased 
opportunities for teacher collaboration as well as strengthen human capital with more professional development before and during the school year.

\section{Eanes Independent School District}

On June 7, 2016, Eanes Independent School District (EISD) began the process of becoming a designated DOI. In accordance with statute, the board of trustees held a public hearing and appointed a committee to develop an LIP. Over the course of four months, the EISD innovation committee - a thirteen-member group representing teachers, parents, campus administrators, and individuals from the local community - drafted an LIP that was eventually adopted and formally approved in mid-December of the same year.

In the case of the EISD DOI initiative, the assumption was that the increased agency would afford innovation, and "create a culture that values imagination, innovative instruction and local control" (p. 3). Some variation of the phrase "local control" was employed nearly forty times throughout the document. The first presented historical background of the DOI legislation and then organized itself around five "innovative governance guidelines" (EISD Plan, 2016). The district would apply the following guidelines for practice to the "unique, local, and instructional needs of its students and community" (EISD Plan, 2016, p. 5): maintain reasonable class sizes in K-4; determine a flexible school start date; adjust instructional minutes and school day length; and implement a local teacher and administrator appraisal system. The document then outlined the educational need for each practice, the manner in which state code inhibited the practice, and finally the "local innovation strategy" (EISD Plan, 2016, p. 5) to implement the practice. In total, EISD requested ten exemptions to fulfill the five innovative governance guidelines. Although the innovative guidelines were, in effect, the same state codes from which the district was exempting itself, the committee framed what could otherwise read as "opting out" as a local choice to "opt in" to new district practices.

One of the innovative governance guidelines included in the LIP related to allowing alternatives to educator certification for distinctive subjects. Like in the AISD LIP, EISD cited struggles staffing innovative classes where certification may not exist or educators with those credentials may not be readily available. Their "local innovation strategies" related to the process for certification and training were much more explicitly stated than with AISD. The principal must specify in writing to the superintendent the reason for the local certification request and whenever possible, lesson plans or curriculum guides to support the "uncertified yet highly qualified" educator will be developed or provided in partnership with certified teachers in the same field. EISD made local guidelines and procedures more transparent in their LIP than AISD.

Again, similar to AISD, Eanes claimed exemptions related to determining a flexible school start date and adjusting instructional minutes and school day length. The EISD LIP rationalized its change to the academic calendar by suggesting that "the current process allows no flexibility in the design and balancing of instructional semesters to meet the needs of students or the wishes of the local Board of Trustees, who represent community interests in this matter" (p. 6). The exemptions permitting Eanes ISD to alter the length of a school day or a school year were sought in order to include additional professional development and collaboration opportunities for 
educators, provide social-emotional benefits for students, and allow for accommodations during parent-teacher conferences and in case of inclement weather. The theme of social capital emerges once more, as teacher collaboration could be facilitated by this new innovative practice and potentially trickle down to classrooms to improve teaching and learning.

Finally, the EISD LIP laid out a plan to administer a locally created teacher and administrator appraisal system better aligned with the district's strategic goals and student assessments. Referring to the statewide appraisal systems, the plan noted, "these systems are designed to meet the needs of the entire state, they do not adequately align with the standards and expectations in Eanes ISD" (p. 8). This approach aligned the districts already strong instructional program coherence with an external district policy, staff evaluations.

\section{Manor Independent School District}

On April 18, 2016, the MISD Board of Trustees unanimously passed a resolution to consider developing an LIP, and then in mid-June opened the conversation to the public during a regularly scheduled board meeting. This coincided with the hiring of a new superintendent, Dr. Royce Avery, who as an assistant superintendent in El Paso ISD had been a part of the committee which finalized their LIP a few months prior to his arrival in Manor. After the public hearing, a 28member committee - comprised of teachers, campus administrators, parents, and local community members - gathered for the first time four days later to begin drafting the district LIP.

The LIP briefly touched on the demographics of the school district. The professional development section mentioned that the reason for its exemption was based on the fact that approximately half of the teachers in MISD had less than five years of experience. It went on to mention that English language learners and economically disadvantaged students (77\%) make up the majority of the student population (Manor Independent School District Local Innovation Plan, 2016, p. 5). MISD currently serves 8,700 students, and the three largest ethnicities are Hispanic (65\%), African American (21\%), and White (2\%). Over $73 \%$ of the MISD student body is identified as "at risk" of dropping out of school (Texas Education Agency website, 2018).

The MISD LIP was the shortest of the three districts but contained the greatest number of exemptions. It was organized around five "areas of innovation," (MISD Plan, 2016, p. 3) including: curriculum; instructional methods; campus governance; parental involvement; and community participation. The document briefly described each of these areas in a single section and then separately listed out the necessary exemptions. Although the stated intent was that the areas of innovation would be reflected throughout, the document read more as two separate lists: the first list indicated the areas in which the district hoped to see change, and the second list outlined the codes that inhibited that change.

The LIP called for exemptions from codes involving minimum teacher certification requirements, student-teacher ratios and class size, minimum attendance for class credit, and behavior management. It also called for exemption from five codes that inhibit opportunities for professional development of teachers. A version of "innovation" was used on average just twice per page, and while local community and local procedures were mentioned, the grander notion of autonomy was never once included. Although HB 1842 deems the submitted LIP valid for five 
years, the MISD plan promised that the innovation committee would "continue to meet over the course of that time period and recommend suggested modifications to the LIP to be adopted by the Board" (MISD Plan, 2016, p. 3).

\section{Discussion}

All three of the district LIPs analyzed here show a high degree of horizontal alignment with regards to the process and implementation of the DOI policy. Over a six-month span in the middle of 2017, each district created and adopted their LIP. The creation of the plans was spearheaded by advisory committees appointed by each of the school boards. There was remarkable consistency in the adoption of certain exemptions, including those of instructional minutes, educator certification, and school calendars. All three LIPs suggested the need for greater autonomy with regard to teacher certification requirements, and each specifically highlighted the difficulty in hiring subjectmatter experts for specialized courses. In other words, compliance with the letter of the law was extremely high.

A more critical lens reveals the way that implementers "filtered" state policy (in this case, DOI) through their own district policies in unique ways to address the distinct challenges they face in their local contexts. Elmore and Fuhrman (1990) indicated conventional notions of local autonomy that frame state-local relationships in terms of "control" over policy in a zero-sum game. Rather than seeing changes in local practice aligned with policy goals as clear evidence of state influence, these scholars suggested that the goals of state policy are achieved if and only if "local policy favors or sanctions it by commission or omission" (p. 92). This dynamic is especially relevant in a policy such as DOI, which requires districts to opt-in and create LIPs that align state policy (in this case, deregulation) with their own localized goals and initiatives.

\section{Common Processes and Procedures, Varied Rationales, and Implementation}

The way in which AISD and EISD crafted their LIPs to align specifically with their district strategic plans was evidence of this local and state policy alignment and reinforcement. The alignment of these external district policies contributes positively to coherence, and is one of the major benefits of deregulation that devolves additional decision-making authority to the district level.

While these two districts were able to successfully "filter" policy to support already undertaken initiatives, AISD alone underscored "competition from charter schools already utilizing this exemption" as a primary challenge and part of their rationale for a pair of claimed exemptions (school calendars, instructional minutes). A major goal of DOI policy is to grant public school districts the same exemptions granted to charter schools. The local charter school growth in Central Texas comes as AISD's enrollment has plummeted, with declines in the last five years in a row. In total, the district has lost about 4,200 students in five years, bringing this year's enrollment to 81,939 (Taboada, 2018). Charter schools have long been able to exempt themselves from state and public school district policies that inhibited local control of resources, staffing, and instruction. In a competitive educational marketplace, AISD and other public school districts may feel pressure to even the playing field. "Approximately half of Manor ISD's teachers have no more than five years of experience in the classroom. With a diverse population mainly comprised of English 
Language Learners and Economically Disadvantaged students, the district's educators must be well-equipped to meet the unique needs of each student" (MISD Plan, p. 5). The impetus for Manor ISD's adoption and contextualized implementation of DOI policy is rooted in typical "urban emergent" challenges faced by the district (Milner, 2013). Manor ISD claimed five exemptions with an eye towards building capacity through increased, more flexible, and responsive professional development for its inexperienced staff. When contrasted with Eanes ISD, significant differences emerge. While both districts exempted from \$25.081 (instructional minutes) and referenced its facilitation of effective professional learning communities, MISD's LIP also suggested, "non-instructional days have been purposefully placed throughout the calendar to allow for teachers to analyze benchmark data" (MISD Plan, p. 5). Eanes on the other hand, rationalized the exemption by stating it would "protect all-important parent-teacher conferences especially in the event of inclement weather days" (MISD Plan, p. 7). That MISD would "filter" its DOI policy exemptions through local policies and priorities that foreground benchmark data analysis reveals the perception of significant accountability pressures from actors within that district.

The AISD and MISD LIPs both seek flexibility in minimum requirements for class credit. This could be illustrative of pressure to meet the needs of different student populations served and/or indicative of current levels of academic achievement across the districts. In order to educate a more diverse population and students from poverty, Manor and AISD pursued additional tools for their toolbox to provide a more individualized and flexible path to graduation. Class size exemptions offer yet another example of "filtering" that takes into account local context for innovative opportunities. The MISD LIP sought exemptions on class sizes so that student groups who need specialized assistance, such as English Language Learners, could have a reduced student/teacher ratio. The Eanes LIP made no mention of student needs in their rationale, only that they wanted local control over the decision.

Overall, while the rationales may have differed, what counted as "innovation" in the LIPs was relatively consistent throughout our analyses. The statement from EISD's LIP indicated that innovation does not necessarily mean ambitious new initiatives beyond the school district's current strategic plan. While some "innovations" were primarily aimed at administrative challenges like hiring teachers and scheduling training or collaboration, all were couched in direct or indirect positive impacts at the classroom level. At the same time, almost all of the innovations presumed a certain level of capacity to provide training, collaborate effectively, positively leverage class size changes, reorganize instructional calendars, and provide alternative graduation pathways that at the school and district level may or may not be present.

\section{Implications}

\section{What Works: Districts "Filter” Policy to Meet Unique Challenges}

All three of the Texas school districts analyzed in this paper implemented DOI policy through their LIPs in ways that addressed needs and challenges unique to their context. Whether it was AISD facing intensifying charter competition, MISD prioritizing training for a relatively novice teaching force, or EISD seeking flexibility in schedule to preserve parent-teacher conferences, districts used DOI to align innovations with areas of importance for them and their stakeholders. At the same 
time, districts were able to align LIPs with strategic action plans to maintain policy coherence. They successfully built up school capacity by carving out spaces for additional, flexible, targeted professional development. Finally, they all recognized and prioritized the value of social capital by seeking exemptions that provided additional opportunities for teacher collaboration through professional learning communities. Instead of discounting the social and political environment, they proactively responded to it and pursued innovations that could potentially improve teaching and learning in their districts.

\section{Inappropriate Scale of Change: Tendency to Try to Do Too Much}

According to HB 1842, school districts are the smallest entity in Texas that can take up the DOI autonomy initiative. In Colorado, the 2008 Innovation Schools Act created a new category of autonomous schools - Innovation Schools. Prompted by the efforts of a few schools in Denver to gain autonomy from district policies, the Innovation Schools Act created a process by which a school could obtain waivers from district policies, state policies, and collective bargaining agreement provisions. Schools could also band together to obtain these waivers through designation as an Innovation School Zone comprised of individual Innovation Schools. The smaller scale of Colorado implementation allows for a number of advantages related to processes and procedures not available to Texas DOI districts.

The fact that a Colorado LIP is developed at the school level provides for a more localized and context-aware decision making process about exemptions and building-level implementation. Local school boards were also encouraged to proactively solicit one or more schools in their district to apply for Innovation School status, and to work collaboratively with schools on the planning and application process. Once plans were developed, Colorado LIPs required evidence that a majority of administrators employed at the school, majority of teachers employed at the school, and majority of the School Accountability Committee members consent to the plan. Because of the school-level scale, stakeholder buy-in was more probable. While majority consent can be coerced and free, fully informed choice about reform adoption is extremely uncommon for teachers, the Colorado procedural structures at least signal to schools that they understand the difference between districts supporting reform and mandating or strongly inducing it. It also provides a potential space to genuinely increase the level of teacher involvement in plan creation and adoption that is more challenging with a broader, district-level LIP.

While Texas DOI policy allows districts to implement coherent innovative reforms aligned with their strategic plans, the coherence crafted (Honig \& Hatch, 2004) in the Colorado context at the school level permits school-wide goal-setting, opportunities for bridging or buffering from external demands from the district and elsewhere, and makes space for central office supporting the schoollevel processes. Schools are working to strategically craft a fit between external demands and the school's goals and strategies.

\section{Cycles of Learning: The Absence of Realistic Assessment and Midcourse Correction}

Effective school reform demands cycles of learning that are iterative and responsive to failed attempts, but HB 1842 does not provide guidelines or processes to encourage this type of policy implementation. In Texas, state law requires only that districts review their plans every five years, 
and makes no mention of mid-course corrections or plan modifications. Colorado has much clearer and more explicit implementation and review guidelines for implementers. Three years after a local school board approves a LIP, and every three years thereafter, the district must review the performance of those schools or zones. If the school is not reaching achievement goals, the local school board can work with the school or zone to revise the LIP to improve the academic performance in the school or zone. Any revisions to the LIP require the consent of a majority of the teachers and a majority of the administrators employed at the school. While three years is hardly a short cycle of learning, it is better than five, and guidelines for revisions are embedded into the monitoring process. Every year, the schools of choice unit of CDE submits an annual report to the Colorado legislature to provide an overview and update of the Innovation Schools program, along with recommendations for legislative changes. The overview includes a summary of the history of the program and current levels of implementation. The update offers current demographics related to socioeconomic status and residence of participating students followed by a description of the innovations implemented. It also includes an overview of the academic performance for students served in innovation schools or zones and includes longitudinal data related to school accountability ratings and median student growth.

Complicating this scenario is the fuzzy alignment between the stated goals of the policy and the performance measures currently in place, both in Texas and Colorado. Absent other measures, the primary indicator of policy performance remains school accountability ratings. As stated earlier, the general logic is that deregulation yields innovation, which in turn boosts student achievement. In reality, it will be all but impossible to credibly link improved district achievement to DOI because of all the other confounding variables, and the perceived practicalness and legitimacy of sanctions-driven accountability has been decidedly mixed (Mintrop \& Sunderman, 2009). This situation reveals a need for tighter alignment between innovation practices and program evaluation that goes beyond accountability ratings and takes into account contingencies and contexts, digging deeper into district/school level strategies that have proved most successful raising student achievement.

\section{The Absence of Meaningful Oversight}

Another significant difference between Texas DOI policy and Colorado's is related to the approval of the LIP itself. If a plan seeks exemptions from state policy in Colorado, the school board must submit it to the commissioner. The difference here is that the commissioner and state board of education offer changes or additions to the plan to increase student achievement, feedback is received and considered at the district level, and then a revised LIP is submitted for approval or denial by the state which must justify its decision in writing. In Texas, on the other hand, once plans are adopted by the school board, they must only inform the commissioner of the new designation, and TEA does not have the authority to approve or deny the LIP. In Colorado, innovation schools have a two-tiered oversight framework. Schools must submit their plans to the local school board for feedback and approval. Then, the same process occurs with the state board. Texas has no oversight mechanism beyond the school board voting on a LIP generated at the district level.

\section{Implementation Recommendations}


MY policy implementation recommendations are rooted in the discussion of findings and their implications in the previous sections. In order to foster meaningful educational innovations that improve teaching and learning at the classroom level, I make the following recommendations:

1) Shrink the scale of implementation by encouraging schools, not districts, to craft and implement LIPs.

This implementation model has a number of positive effects. First of all, it allows for a more localized and context-aware decision making process about exemptions and building-level implementation. It has the potential to improve teacher and administrator buy-in, making them more prominent in the process. It also provides space for coherence to be crafted by school-level actors who can align flexible goal setting with other initiatives.

2) Slow the pace of implementation and improve state oversight.

The rapid rate of uptake of DOI in Texas paired with almost nonexistent state oversight will probably be associated with significant problems related to adverse selection and inadequate district capacity. Using an economic lens, the sometimes related divergent objectives problem occurs when agents pursue their own objectives at the expense of the principal's objectives. While the stated goal of DOI is to enable schools to develop and implement novel approaches to teaching and learning using exemptions as incentives, it's never a simple task to realign the preferences of any group using policy alone. With the exemptions pursued by districts under DOI, it remains to be seen if principal-agent goals and behavior will turn out to be truly aligned. I suggest creating more stringent review procedures for new plans with enhanced feedback and heightened progressmonitoring.

3) Shorten and enhance the cycles of learning with improved performance measures.

As it stands right now, DOIs in Texas are only required to review their LIP after five years. While some districts that already have a deep culture of inquiry and accountability will undoubtedly engage in iterative cycles of learning through program evaluation without incentive or mandate, the state education agency and policymakers can support this process by providing specific guidelines and tools to districts. If districts shorten their self-assessment cycles, they can respond better and revise strategies accordingly. Moving beyond standardized-testing as the only assessment measure to include more qualitative measures like interviews with stakeholders could also be an important tool for districts to improve their implementation.

\section{Conclusion}

In the broadest sense, the ultimate performance measure for DOI policy will be the traditional public school district's institutional survival in the competitive educational marketplace, reflected in enrollment and funding. From this perspective, DOI could be perceived as something of a Trojan horse, leveling the playing field for side-by-side comparisons with charters and private schools in future battles for public dollars and state support that are highly politicized and may have damaging consequences for equity. Powerful interest groups with substantial interests in introducing market discipline (deregulation) into education are important policy influencers and from a business perspective, schools and students are increasingly regarded as an untapped market. Regardless, 
hundreds of districts across the state, whose political clout makes them not just implementers but policymakers as well, have elected to embrace decentralization and adopt local plans that might bring this potential "Trojan horse" within their "city walls". The pull to address accountability, budget, enrollment, and demographic pressures alongside the push to seize increased autonomy and decision making authority to meet the needs of diverse students and families proved powerful forces for the majority of public school districts in Texas. While my analysis of three Central Texas districts has anecdotally shown that compliance is high, effectiveness and realization of the policy goals (themselves subject to interpretation about their true motivations) are inconsistent. In any case, deregulation as an educational reform further shifts responsibility for increased achievement and equity away from the state and further onto the local districts- what they will manage to do with that responsibility, innovations or otherwise, is an open question.

\section{References}

Austin ISD. (2017). Austin independent school district local innovation plan [Archive]. Retrieved from https://www.austinisd.org/sites/default/files/dept/ina/Austin_ISD_District_of_Innovation_Plan.pdf

Berends, M. (2015). Sociology and school choice: What we know after two decades of charter schools. Annual Review of Sociology, 41, 159-180.

Bryk, A.S., Sebring, P.B., Allensworth, E., Luppescu, S, \& Easton, J.Q. (2010). Organizing schools for improvement: Lessons from Chicago. Chicago, IL: University of Chicago Press.

Buckley, J., \& Schneider, M. (2005). Are charter school students harder to educate? Evidence from Washington, D.C. Educational Evaluation and Policy Analysis, 27, 365-380.

Bulkley, K., \& Fisler, J. (2003). A decade of charter schools: From theory to practice. Educational Policy, 17(3), 317-342.

Childs, J., \& Russell, J. L. (2017). Improving low-achieving schools: Building state capacity to support school improvement through race to the top. Urban Education, 52(2), 236-266.

Chubb, J.E., \& Moe, T.M. (1990). Politics, markets, and America's schools. Washington, D.C.: Brookings Institution.

Colorado Department of Education. (2018). 2018 Districts of innovation annual report. Retrieved from https://www.cde.state.co.us/choice/2018innovationschoolsreport

DiMartino, C., \& Jessen, S.B. (2016). School brand management: The policies, practices, and perceptions of branding and marketing in New York City's public high schools. Urban Education, 51(5), 447.

Districts of Innovation, Texas Education Code $\S 12 \mathrm{~A}$ (2015).

Eanes ISD. (2016). A district plan for innovation \& local control [Archive]. Retrieved from http://eanesisdnet.finalsite.com/uploaded/District/Our_District/Projects/doi/Final_Eanes_ISD_Innovation Plan_with_Summary_Board_Approved_12.13.16.pdf?1481748966541

Eanes ISD. (2018). Our district [Website, archive, database]. Retrieved from https://www.eanesisd.net/district

Elmore, R., \& Fuhrman, S. (1995). Opportunity to learn and the state role in education. Teachers' College Record, 96(3), 433-458.

Holme, J.J. (2002). Buying homes, buying schools: School choice and the social construction of school quality. Harvard Educational Review, 72(2), 177.

Honig and Hatch. (2004). Crafting coherence: how schools strategically manage multiple, external demands. Educational Researcher, v33, n16.

Hoxby, C.M. (2003). School choice and school productivity. Could school choice be a tide that lifts all boats? In The economics of school choice (pp. 287-342). Chicago, IL: University Chicago Press.

Frankenberg, E., Siegel-Hawley, G., Wang, J., \& Orfield, G. (2012). Choice without equity: Charter school segregation and the need for civil rights standards. Los Angeles, CA: The Civil Right Project/Proyecto Derechos Civiles at UCLA.

Friedman, M. (2009). Capitalism and freedom. Chicago, IL: University of Chicago Press.

Fuller, B. (2002). The public square, big or small? Charter schools in political context. In B. Fuller (Ed.), Inside charter schools: The paradox of radical decentralization (pp. 12-65). Cambridge, MA: Harvard University Press. 


\section{Childs: Districts of innovation: Combating a wicked problem in education}

Fusarelli, L.D. (2004). The potential impact of the No Child Left Behind Act on equity and diversity in American education. Educational Policy, 18, 71-94.

Fuhrman, S.H., \& Elmore, R.F. (1990). Understanding local control in the wake of state education reform. Educational Evaluation and Policy Analysis, 12(1), 82- 96.

Gleason, P.M. (2014, June 9-10). What's the secret ingredient? Searching for policies and practices that make charter schools successful. Presented at Crossroads of America: The Intersection of Research and Policy in the Indiana School Choice Ecosystem, University of Notre Dame: Center for Research on Educational Opportunity.

Leithwood, K., Harris, A., \& Strauss, T. (2010). Leading school turnaround: How successful leaders transform lowperforming schools. San Francisco, CA: Jossey-Bass.

Levin, H. M. (2012). Some economic guidelines for design of a charter school district. Economics of Education Review, 31(2), 331-343. doi: 10.1016/j.econedurev.2011.08.010

Liebman, J.S., Alter, J., Begeman, S., Ghaznavi, Z., Goldiner, A., Grossman, J., \& Wilds, C. (2015). Texas innovation schools: A pathway to success for autonomous schools in Texas. Retrieved from http://www.raiseyourhandtexas.org/wp-content/uploads/2015/09/Texas-InnovationSchools ResearchReport.pdf

Lubienski, C. (2003). Innovation in education markets: Theory and evidence on the impact of competition and choice in charter schools. American Educational Research Journal, 40(2), 395443.

Lubienski, C. (2005). Public schools in marketized environments: Shifting incentives and unintended consequences of competition-based educational reforms. American Journal of Education, $111(4), 464-486$.

Lubienski, C. (2007). Marketing schools: Consumer goods and competitive incentives for consumer information. Education and Urban Society, 40(1), 118-141.

Malen, B. (2003). Tightening the grip? The impact of state activism on local school systems. Educational Policy, 17(2), 195-216.

Malen, B. (2006). Revisiting policy implementation as a political phenomenon: The case of Reconstitution Policies. In M.I. Honig (Ed.), New Directions in Education Policy Implementation (pp. 83-104). Albany, NY: SUNY Press.

Manor ISD. (2016). Local innovation plan [Archive]. Retrieved from https://1.cdn.edl.io/bed0v7o7h7u5ZxHrxZwag2odHO0ZIXPzH3ATeszjK0rKpreK.pdf

McCandless, T. (2015). Classing schools. Discourse: Studies in the Cultural Politics of Education, 36(6), 808-820.

Milner, H. R. (2013). Chapter 1: Analyzing poverty, learning, and teaching through a critical race theory lens. Review of Research in Education, 37, 1-53.

Mintrop, H., \& Sunderman, G.L. (2009). Predictable failure of federal sanctions-driven accountability for school improvement - And why we may retain it anyway. Educational Researcher, 38, 353-364.

Mintrop, H., \& Trujillo, T. M. (2005). Corrective action in low performing schools: Lessons from NCLB implementation from first-generation accountability systems. Education Policy Analysis Archives, 13(48).

Miron, G., Urschel, J.L., Mathis, W.J., \& Tornquist, E. (2011). Schools without Diversity: Education Management Organizations, Charter Schools, and the Demographic Stratification of the American School System. Education and the Public Interest Center.

Preston, C., Goldring, E., Berends, M., \& Cannata, M. (2012). School innovation in district context: Comparing traditional public schools and charter schools. Econ. Educ. Rev. 31(2), 318-30.

Renzulli, L.A., \& Evans, L. (2005). School choice, charter schools, and white flight. Social problems, 52(3), 398418.

SB1241: Hearing before the Texas State Senate Committee on Education, $84^{\text {th }}$ Legislature. (2015, April 7). (testimony of Steve Swanson, David Anthony, Brock Gregg, Patti Quinzi, Holley Eaton, Duncan Klussman, John Grey). Retrieved from http://tlcsenate.granicus.com/MediaPlayer.php?clip_id=9587

SB1241: Hearing before the Texas State House of Representatives Committee on Public Education, $84^{\text {th }}$ Legislature. (2015, May 19). (testimony of Lonnie Hollingsworth, David Anthony, Ted Melina Raab, Monty Exter). Retrieved from http://tlchouse.granicus.com/MediaPlayer.php?view_id=37\&clip_id=11252

Schneider, M., \& Buckley, J. (2002). What do parents want from schools? Evidence from the internet. Educational Evaluation and Policy Analysis, 24(2), 133-144.

Stewart, M.S., \& Good, A.G. (2016). Marketing, information, and parental choice: A 


\section{Childs: Districts of innovation: Combating a wicked problem in education}

comparative case study of third-party, federally funded out-of-school-time services. Peabody Journal of Education, 91(1), 100.

Stulberg, L. (2004). What history offers progressive choice scholarship. In E. Rofes \& L. Stulberg (Eds.), The emancipatory promise of charter schools: Towards a progressive politics of school reform (pp. 1-54). Albany, NY: State University of New York Press.

Taboada, Michelle. (2018). Austin charter schools hit 25,000 students as Texas gives them a boost. The Austin American Statesman. Retrieved from https://www.mystatesman.com/news/local-education/austin-charterschools-hit-000-students-texas-gives-them-boost/252BHkapaX8T13Yeo6Y1BP/

Texas Association of School Boards. (2018). Districts of innovation [Website, archive, database]. Retrieved from https://www.tasb.org/Services/Legal-Services/TASB-School-Law-eSource/Governance/Districts-ofInnovation.aspx

Texas Education Agency. (2015). Snapshot 2015 [Data set]. Retrieved from https://rptsvr1.tea.texas.gov/perfreport/snapshot/2015/

Texas Education Agency. (2016). Districts of innovation [Archive]. Retrieved from http://tea.texas.gov/Texas_Schools/General_Information/Innovation/Districts_of_Innovation/

Texas Legislature Online. (2015). Senate bill 1241, 84(R) [Database]. Retrieved from http://www.capitol.state.tx.us/BillLookup/History.aspx?LegSess=84R\&Bill=SB1241\#vote160

The Texas Tribune. (2018). Manor ISD [Website, archive, dataset]. Retrieved from http://schools.texastribute.com/districts/manor-isd

VanGronigen, B.A., \& Meyers, C.V. (2017). How state education agencies are administering school turnaround efforts: 15 years after No Child Left Behind. Educational Policy, 0895904817691846.

Wells, A. S., Vasudeva, A., Holme, J., \& Cooper, C. (2002). The politics of accountability: California school districts and charter school reform. In A. Wells (Ed.), Where charter school policy fails: The problems of accountability and equity (pp. 29-53). New York, NY: Teachers College Press.

Wilson, T.S., \& Carlsen, R.L. (2016). School marketing as a sorting mechanism: A critical discourse analysis of charter school websites. Peabody Journal of Education, 91(1), 24.

Wohlstetter, P., Smith, J., \& Farrell, C.C. (2013). Choices and Challenges: Charter School Performance in Perspective. Cambridge, MA: Harvard Education Press. 